\title{
The interaction between Myc and Miz1 is required to antagonize TGF $\beta$-dependent autocrine signaling during lymphoma formation and maintenance
}

\author{
Jan van Riggelen, ${ }^{1,2,7}$ Judith Müller, ${ }^{3,7}$ Tobias Otto, ${ }^{4,7}$ Vincent Beuger, ${ }^{3,5}$ Alper Yetil,, ${ }^{1,2}$ \\ Peter S. Choi, ${ }^{1,2}$ Christian Kosan, ${ }^{6}$ Tarik Möröy, ${ }^{6}$ Dean W. Felsher, ${ }^{1,2,8,10}$ and Martin Eilers ${ }^{3,8,9}$ \\ ${ }^{1}$ Department of Medicine, Division of Oncology, Stanford University, School of Medicine, Stanford, California 94304, USA; \\ ${ }^{2}$ Department of Pathology, Division of Oncology, Stanford University, School of Medicine, Stanford, California 94304, USA; \\ ${ }^{3}$ Theodor Boveri Institute, Biocenter, University of Würzburg, 97074 Würzburg, Germany; ${ }^{4}$ Dana-Farber Cancer Institute, \\ Boston, Massachusetts 02115, USA; ${ }^{5}$ TaconicArtemis GmbH, 51063 Koeln, Germany; ${ }^{6}$ Institut de Recherches Cliniques de \\ Montreal, Université de Montréal, Montreal, Québec H2W 1R7, Canada
}

The Myc protein suppresses the transcription of several cyclin-dependent kinase inhibitors (CKIs) via binding to Miz1; whether this interaction is important for Myc's ability to induce or maintain tumorigenesis is not known. Here we show that the oncogenic potential of a point mutant of Myc (MycV394D) that is selectively deficient in binding to Miz1 is greatly attenuated. Binding of Myc to Miz1 is continuously required to repress CKI expression and inhibit accumulation of trimethylated histone $\mathrm{H} 3$ at Lys 9 (H3K9triMe), a hallmark of cellular senescence, in T-cell lymphomas. Lymphomas that arise express high amounts of transforming growth factor $\beta-2$ (TGF $\beta-2)$ and TGF $\beta-3$. Upon Myc suppression, TGF $\beta$ signaling is required to induce CKI expression and cellular senescence and suppress tumor recurrence. Binding of Myc to Miz1 is required to antagonize growth suppression and induction of senescence by TGF $\beta$. We demonstrate that, since lymphomas express high levels of TGF $\beta$, they are poised to elicit an autocrine program of senescence upon Myc inactivation, demonstrating that TGF $\beta$ is a key factor that establishes oncogene addiction of T-cell lymphomas.

[Keywords: Myc; Miz1; senescence; TGF $\beta$; lymphoma; T-cell]

Supplemental material is available at http://www.genesdev.org.

Received September 9, 2009; revised version accepted April 22, 2010.

Enhanced expression of the MYC oncogene is a hallmark of many human tumors, and multiple experiments in tissue culture and in transgenic animals document the oncogenic potential of deregulated MYC expression (Oster et al. 2002). To explain these observations, one needs to understand the molecular mechanisms by which the encoded protein Myc promotes and maintains tumor formation.

Myc is a nuclear protein that forms a specific DNAbinding complex with a partner protein termed Max. Most, but not all, functions of Myc depend on interaction with Max: For example, Myc forms a complex with TfIIIb to stimulate transcription of RNA polymerase III genes independently of Max (Steiger et al. 2008). Myc/Max complexes

\footnotetext{
${ }^{7}$ These authors contributed equally to this work.

${ }^{8}$ These authors are senior authors of this study.

Corresponding authors.

9E-MAIL martin.eilers@biozentrum.uni-wuerzburg.de; FAX 49-9031-3184113.

${ }^{10}$ E-MAIL dfelsher@stanford.edu; FAX (650) 725-1420.

Article is online at http://www.genesdev.org/cgi/doi/10.1101/gad.585710.
}

interact in at least two different manners with DNA. They can bind directly to specific E-box sequences and, upon binding, stimulate transcription of a large group of target genes (Eilers and Eisenman 2008). They can also be recruited to the Mizl transcription factor, leading to a complex that binds to the core region of several promoters. In this manner, Myc/Max complexes repress transcription of target genes of Mizl.

How these different complexes contribute to transformation by Myc is only beginning to emerge. Several genes that are targets for transcriptional activation of Myc are essential for tumor formation: For example, odc1 (encoding ornithine decarboxylase) is haploinsufficient for Mycinduced lymphomagenesis, but not for normal development, demonstrating that Myc-dependent up-regulation of odc1 is critical for Myc to drive tumorigenesis (Nilsson et al. 2005). Similarly, multiple target genes of Myc encode components of the protein synthesis machinery, arguing that enhancing cell growth and translation is one mechanism by which Myc promotes transformation. In strong 
support of this hypothesis, reducing the protein biosynthetic capacity by removing one copy of the rpl24 gene, which encodes a protein of the large ribosomal subunit, does not impair normal development, but abrogates Mycinduced B-cell lymphomagenesis (Barna et al. 2008).

In tissue culture, ectopic expression of Myc suppresses the cell cycle arrest that occurs in response to several antimitogenic signals such as transforming growth factor $\beta$ (TGF $\beta)$, since Myc represses expression of the cyclindependent kinase inhibitors (CKIs) p15ink4b, p21cip1, and p57kip2 via interaction with Mizl (Seoane et al. 2001; Gebhardt et al. 2006). Repression of CKI expression by Myc is also documented by enhanced CKI expression in mice deleted for c-Myc and N-Myc (Knoepfler et al. 2002; Oskarsson et al. 2006). Indeed, the phenotypes of Myc deletion mutants are ameliorated by codeletion of CKIs, suggesting that repression of CKI expression may be a critical function of Myc in tumorigenesis (Oskarsson et al. 2006; Zindy et al. 2006).

Inactivation of oncogenic Myc in T-cell lymphomas as well as in a variety of additional tumor types causes rapid and sustained tumor regression (Pelengaris et al. 2002; Shachaf et al. 2004). The observation that the suppression of a single oncogene back to physiologic levels can induce dramatic tumor regression has suggested the notion that tumors are addicted to particular oncogenes (Weinstein 2002; Felsher 2008). A possible mechanism underlying oncogene addiction is suggested by the observation that tumor cells in which Myc is inactivated undergo cellular senescence associated with the induction of CKIs (Wu et al. 2007). Thus, cellular senescence may contribute to tumor regression upon oncogene inactivation.

Conditional transgenic mouse models provide a particularly tractable strategy for examining the role of $\mathrm{Myc}$ expression in the induction and maintenance of tumorigenesis (Felsher and Bishop 1999; D'Cruz et al. 2001; Pelengaris et al. 2002). Here, we use transgenic mouse models that employ a doxycycline-regulated system of conditional gene expression to interrogate the role of the interaction of Myc with Mizl in the development of T-cell lymphomas. We uncovered that Mizl and Myc are critical to the regulation of a TGF $\beta$-dependent feedback loop that plays an important role in the mechanism by which Myc is restrained from inducing lymphomas, and the mechanism by which Myc inactivation elicits oncogene addiction and induces tumor regression.

\section{Results}

In order to interact with Miz1, the Myc oncoprotein requires a specific surface on the outside of the helix-loophelix domain that is defined by a series of loss-of-interaction point mutants. One of these mutants, MycV394D, is deficient in Miz1-mediated repression, but retains the ability to activate transcription (Herold et al. 2002; Gebhardt et al. 2006). In order to study the role of the interaction of Myc with Mizl during lymphomagenesis, we generated a series of founder mice that express either wild-type Myc or MycV394D under the control of a doxycycline-responsive minimal promoter (tetO-MYC). Previous work has demon- strated that mice expressing wild-type Myc rapidly develop T-cell lymphomas when crossed to mice expressing a doxycycline-repressible transactivating protein (tTA) under the control of the immunoglobulin heavy chain enhancer and the SR $\alpha$ promoter (E $\mu$ SR-tTA) (Felsher and Bishop 1999).

Immunoblotting of thymus lysates of double-transgenic mice at 5 wk of age demonstrated robust expression of human Myc in animals derived from eight out of 10 founder lines, which were comparable with the levels of Myc protein in HeLa cells (Supplemental Fig. 1A). In a pilot experiment, we selected animals of two of the lines expressing MycV394D (designated VD-1 and VD-2) and one line expressing wild-type Myc (wt-1), which expressed similar levels of human Myc (Supplemental Fig. 1A,B). We monitored tumor development in both double and singletransgenic mice maintained in the absence of doxycycline over a time period of at least $60 \mathrm{wk}$. The results showed that lymphomagenesis was significantly delayed in both double-transgenic V394D lines relative to the wt-1 mice ( $P=0.0084$ for VD-2 and $P<0.0001$ for VD-1, respectively) (Supplemental Fig. 1C,D). No lymphomas developed in single-transgenic mice. The findings suggested that MycV394D is significantly impaired in its oncogenic potential relative to wild-type Myc.

In order to exclude that the difference in tumor development observed in this experiment was due to founderspecific differences in the time course of transgene induction during development, we repeated the experiment using a protocol that induces expression of the transgene 3 wk after birth (Fig. 1A). Control experiments confirmed that expression of both MycV394D and wild-type Myc was tightly repressed in the presence of doxycycline (Fig. 1B). We also included mice from two more founder lines (VD-3 and wt-2) to further reduce potential variations due to differences between individual founder lines; mice from all founder lines expressed similar levels of human Myc (less than twofold variation) (Supplemental Fig. 1A,B). Monitoring this cohort of mice showed that the median survival time of mice expressing MycV394D is more than twice as long as that of mice expressing wildtype Myc (47 wk versus 20.57 wk; $P<0.0001$ ) (Fig. 1C). As before, no tumors developed in single-transgenic animals, demonstrating that tumor development was due to the expression of the Myc transgene ("control") (Fig. 1C). The tumor development was slower in all three V394D lines relative to the two wild-type founder lines, although there was some variation between founder lines of the same genotype (Supplemental Fig. 2). Immunoblots showed that this variation was not due to different levels of Mizl protein (data not shown). All 29 tumors that we analyzed by FACS were of lymphoblastic T-cell origin, since they expressed the T-cell-specific surface antigen CD3 (data not shown) and CD4, as well as variable levels of the CD8 antigen. There was no consistent difference in expression of the CD4 and CD8 surface markers between lymphomas arising in mice expressing wild-type Myc or MycV394D (Fig. 1D). We concluded that MycV394D is impaired in its ability to induce T-cell lymphomas.

We analyzed between four and 10 individual tumors arising in mice expressing wild-type Myc or MycV394D 
A

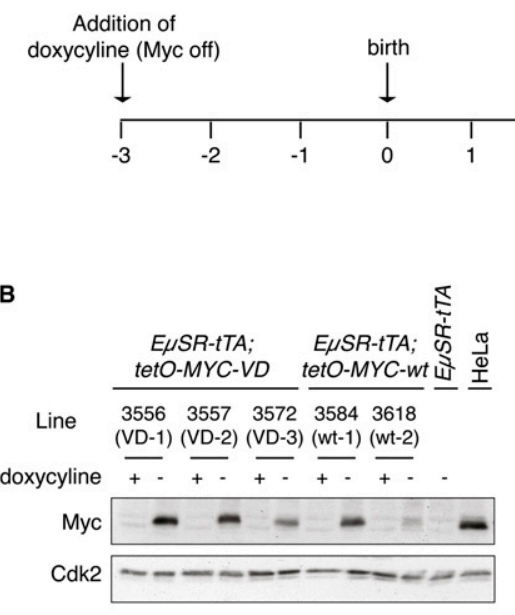

C

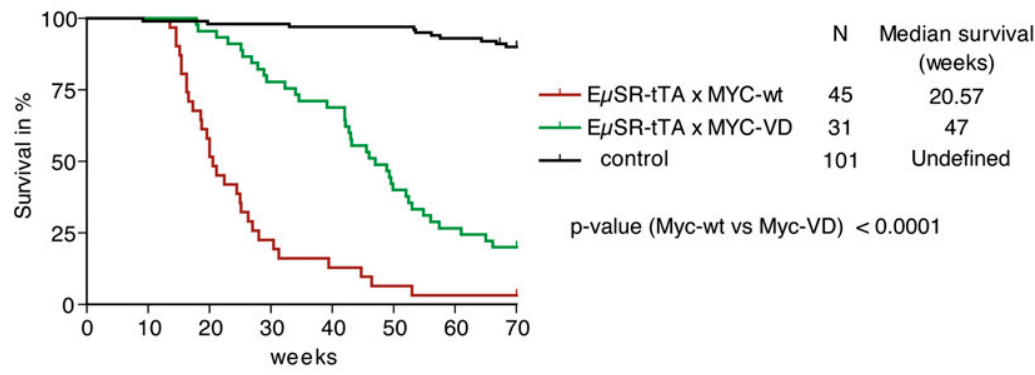

D

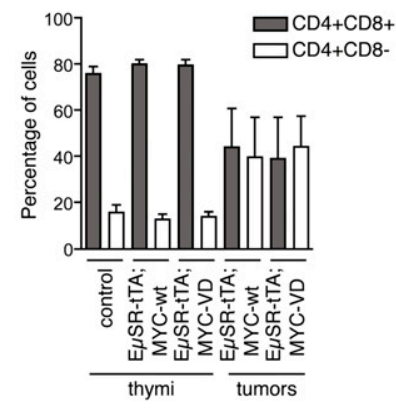

Figure 1. MycV394D is impaired relative to wild-type Myc in its ability to induce lymphomas. (A) Time course of the experiment. $(B)$ Doxycycline-regulated expression of Myc in animals derived from the five founder lines selected for the experiment. Double-transgenic mice were sacrificed at the time points shown in $A$. Immunoblots of thymic lysates were probed with antibody 9E10, which detects human Myc, and Cdk2 as loading control. For comparison, equal amounts of a HeLa cell lysate were loaded in the last lane. $(C)$ Kaplan-Meier plot summarizing the tumor development in double-transgenic mice expressing wild-type Myc and MycV394D, as well as the single-transgenic controls; doubletransgenic mice of different founder lines with the same genotype are summarized in one graph here. The number of mice analyzed is shown on the right, together with the median survival of mice for each genotype. The $P$-value is shown for the difference between double-transgenic mice expressing wild-type Myc and MycV394D, and was calculated using a log-rank test. All singletransgenic or nontransgenic mice are included as one control group. $(D)$ Summary of FACS analyses documenting the percentage of cells expressing the T-cell markers CD4 and CD8 in nontransgenic mouse (control) thymus $(n=2)$, and in thymi (wild-type Myc: $n=7$; MycV394D: $n=7$ ) and lymphomas (wild-type Myc: $n=10$; MycV394D: $n=11$ ) arising in mice of the indicated genotypes. by immunohistochemistry and immunoblotting to determine the cause of this difference. Terminal desoxynucleotide transferase (TUNEL) staining showed that the percentage of apoptotic cells was significantly lower in tumors arising in MycV394D mice, demonstrating that enhanced apoptosis cannot account for the delayed tumorigenesis (Fig. 2A). The lower degree of apoptosis is consistent with several observations documenting a proapoptotic role of the Myc/Mizl complex (Patel and McMahon 2006; Herkert et al. 2010). Using Ki67 as marker to determine the percentage of cells that have not exited from the cell cycle revealed no difference between both tumor types (Fig. 2A). Tumorigenesis is also limited by an irreversible form of cell cycle arrest termed senescence (Prieur and Peeper 2008). Staining for trimethylation of histone H3 at Lys 9 (H3K9triMe), a histone modification that has been causally implicated in senescence, revealed a strong and highly significant increase in the percentage of H3K9triMe- positive cells in tumors arising in mice expressing MycV394D relative to wild-type Myc (Fig. 2A; Braig et al. 2005). Strikingly, double staining revealed that lymphomas expressing MycV394D, but not those expressing wild-type Myc, were characterized by the presence of a significant fraction of cells that stain positive for both Ki67 and $\mathrm{H} 3 \mathrm{~K} 9$ triMe, demonstrating that binding to Miz1 is required to prevent accumulation of H3K9triMe, but not for maintaining Ki67 expression (Fig. 2B). Notably, the percentage of cells expressing senescence-associated $\beta$-galactosidase (SA$\beta$-Gal) was lower than that of cells expressing H3K9triMe, and revealed only a trend toward an increased number of positive cells in MycV394D lymphomas (Fig. 2A). Similarly, expression of Dec1 and DcR2, two markers of oncogene-induced senescence, did not discriminate between lymphomas arising in MycV394D and in wild-type Myc transgenic mice (Collado et al. 2005; data not shown). The data show that the delayed tumor development in 
A
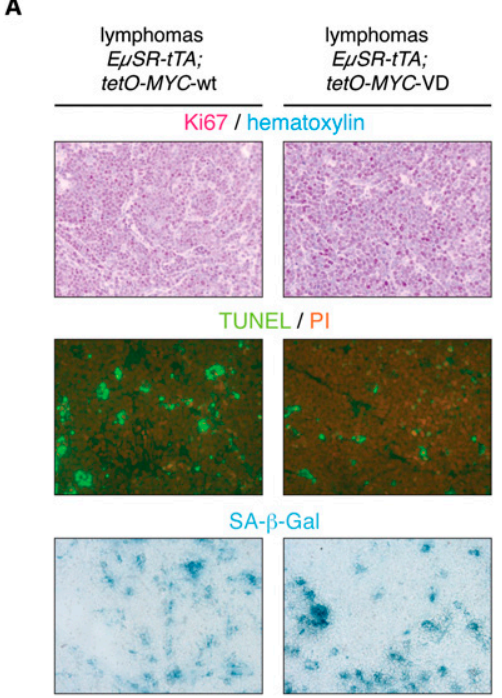

H3K9triMe / hematoxylin

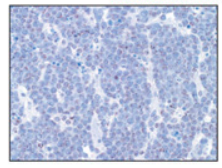

D

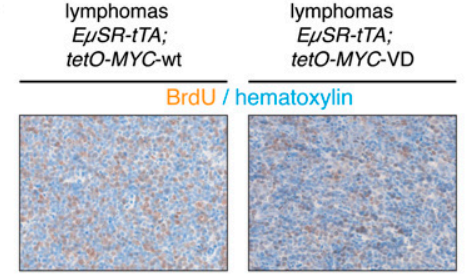

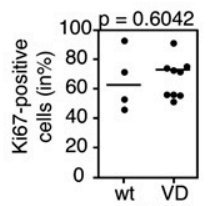
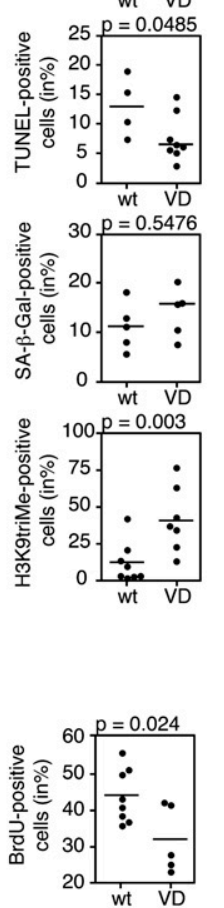

B

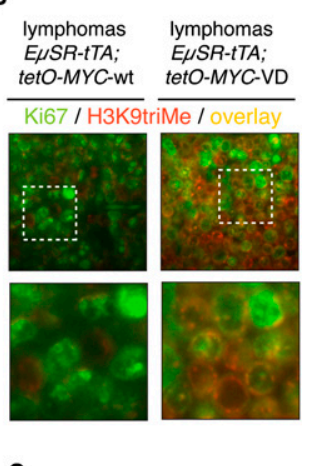

C
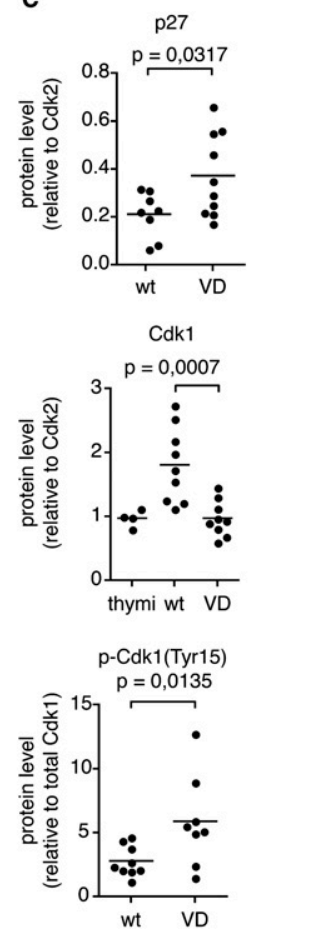

Figure 2. Molecular analysis of lymphomas arising in mice expressing wild-type Myc or MycV394D. (A) The left panels show representative sections stained with the indicated antibodies or reagents to detect the presence of Ki67, a marker of cells in the G1, S, or G2 (but not G0) phases of the cycle; of apoptotic cells (using terminal desoxynucleotide transferase and biotinylated dUTP "TUNEL"); and of senescent cells using either SA$\beta$-Gal or H3K9triMe as markers. The right panels show a quantification of stainings of multiple lymphomas for each marker together with the $P$-value determined by a two-tailed Mann-Whitney test. $(B)$ Immunofluorescence pictures of representative sections of lymphomas stained with antibodies against both Ki67 and H3K9triMe. Pictures in the bottom row show enlargements of the indicated regions documenting the presence of double-positive cells in MycV394D lymphomas. (C) Quantification of immunoblots documenting expression of $\mathrm{p} 27, \mathrm{Cdk} 1$, and Cdk1 phosphorylated at Tyr 15 in lymphomas expressing either wildtype Myc or MycV394D. (D) The panel on the right shows the percentage of lymphoma cells incorporating BrdU. Mice of each genotype that had developed lymphomas were injected with BrdU $3 \mathrm{~h}$ before they were sacrificed (wild-type Myc: $n=8$; MycV349D: $n=5$ ). The pictures show representative sections stained with $\alpha$-BrdU antibodies.
MycV394D mice relative to wild-type mice correlates with the accumulation of cells that express one marker (H3K9triMe), but not other markers (e.g., SA- $\beta$-Gal), of senescence. We therefore call these "senescent-like" cells.

To better understand why tumor development is delayed in V394D lymphomas, we probed immunoblots of lymphomas with antibodies directed against the cell cycle inhibitor p27Kip1 (Fig. 2C). Expression of p27 was significantly increased in lymphomas driven by MycV394D relative to lymphomas expressing wild-type Myc, pointing to a defect in proliferation of MycV394D lymphomas. Since Ki67 is expressed after the mid-G1 phase of the cell cycle, whereas $\mathrm{p} 27$ blocks progression at the G1/S boundary, the data suggest a defect in progression through the cell cycle (Gerdes et al. 1984; Polyak et al. 1994). Strongly supporting this notion, lymphomas expressing MycV394D displayed significantly lower levels of Cdk1(Cdc2), which is expressed in the G2 and M phases of the cell cycle and is required for entry into mitosis (Fig. 2C). Furthermore, the fraction of Cdk1 phosphorylated at Tyr 15 was elevated in
MycV394D lymphomas. Dephosphorylation at Tyr 15 by the Cdc25 phosphatase is required for activation of Cdk1, arguing that Cdk1 is inactive in MycV394D lymphomas (Fig. 2C; Kumagai and Dunphy 1991). Finally, we labeled a total of 13 (wild-type Myc: $n=8$; MycV394D: $n=5$ ) lymphomas in vivo with $\mathrm{BrdU}$, and observed that the fraction of cells incorporating BrdU was significantly lower in MycV394D lymphomas compared with lymphomas expressing wild-type Myc $(P=0.024)$ (Fig. 2D). We concluded that lymphoma cells expressing MycV394D have a defect in progression through the $\mathrm{S}$ and $\mathrm{G} 2$ phases of the cell cycle.

Several pathways have been implicated in causing senescence. In human fibroblasts expressing oncogenic $R A S$, senescence involves a DNA damage response caused by $R A S$-induced hyperreplication, ultimately leading to phosphorylation and activation of p53 by the Chk1 kinase (Di Micco et al. 2006). Senescence can also occur as a consequence of induction of the Arf protein, which inhibits the Mdm2 ubiquitin ligase, leading to the DNA damageindependent stabilization of p53 (Kamijo et al. 1997). 
To explore whether differences in either pathway account for the delay in lymphoma formation in MycV394D transgenic mice, we probed lysates of lymphomas arising in both wild-type Myc and MycV394D mice with specific antibodies directed against p19Arf, p53, and p53 phosphorylated at Ser 18, a hallmark of DNA damage-dependent activation of p53 (Fig. 3A; Shieh et al. 1997). Levels of Arf protein were elevated to a similar extent in lymphomas of either genotype relative to nontransgenic thymus and to prelymphomagenic cells (Supplemental Fig. 3A). These levels were low relative to those found in $\mathrm{p} 53^{-/-}$fibroblasts, and apparently were not sufficient to fully inhibit Mdm2, since p53 levels remained unaltered in lymphomas relative to prelymphomagenic and normal cells. Similarly, levels of cdkn2a(p19Arf) mRNA did not differ between lymphomas of either genotype (Fig. 3B). To further rule out that variations in Arf level accounted for the difference in survival, we analyzed expression of Arf in all animals of the wt-1 and VD-2 founder lines and excluded all animals with detectable Arf levels; analysis of the remaining animals still revealed a highly significant difference in survival (Supplemental Fig. 3B). We observed no significant accumulation of p53 phosphorylated at Ser 18 in lymphomas, arguing that the extent of Myc-induced DNA damage may be low in this tumor model. Consistent with this notion, sequencing of the DNA encoding the DNAbinding domain of p53 from nine individual lymphomas revealed no mutations in this domain in lymphomas of either genotype (data not shown). Finally, levels of Chk1 phosphorylated at Ser 345, which is an indicator of replicative stress, were very low in several tumors that we analyzed, and did not differ consistently between lymphomas arising in wild-type Myc and MycV394D mice (Supplemental Fig. 3C). Taken together, these observations make it unlikely that elevated levels of active p53 cause the accumulation of senescent-like cells in MycV394D lymphomas.

Senescence can also be caused by sustained inhibition of cyclin-dependent kinases in a p53-independent man- ner. Specifically, p16Ink4a, p15Ink4b, and p21Cip1 have been implicated in mediating senescence in response to oncogenic stress (Missero et al. 1996; Serrano et al. 1997; Malumbres et al. 2000). Reverse transcription/quantitative PCR (RQ-PCR) analysis showed that lymphomas expressing MycV394D or wild-type Myc displayed equal levels of $c d k n 1 a$ (encoding p21Cip1), cdkn1b (p27Kip1), and $c d k n 2 a$ (p16Ink4a) (Fig. 3B). In contrast, MycV394D lymphomas expressed significantly elevated levels of $c d k n 2 b$ (p15Ink4b) and $c d k n 1 c$ (p57Kip2) relative to lymphomas expressing wild-type Myc.

Both $c d k n 2 b$ and $c d k n 1 c$ are directly repressed by Myc via Miz1, suggesting that their enhanced expression may reflect the lack of Mizl-dependent repression in lymphomas arising in MycV394D mice (Staller et al. 2001; Adhikary et al. 2003). Chromatin immunoprecipitation (ChIP) experiments confirmed that both Myc and Mizl were bound to the start site of the $c d k n 2 b$ promoter in lymphoma cells, consistent with the suggestion that Myc actively suppresses expression of $\mathrm{p} 15 \mathrm{Ink} 4 \mathrm{~b}$ via interaction with Miz1 (Fig. 4A). To test this notion directly, we cultured cells from both Myc and MycV394D lymphomas and added doxycycline to switch off expression of Myc. Addition of doxycycline led to a rapid induction of $c d k n 2 b$ mRNA and p15Ink4b protein in cells expressing wild-type Myc (Fig. 4B,C). Cells expressing MycV394D displayed elevated levels of $c d k n 2 b$ mRNA and p15Ink4b protein even in the absence of doxycycline, despite robust expression of the MycV394D protein, confirming that MycV394D is compromised in transcriptional repression of $c d k n 2 b$ (Fig. 4B,C; Gebhardt et al. 2006). Addition of doxycycline to cells expressing MycV394D led to a moderate further increase in $c d k n 2 b$ expression, arguing that MycV394D is compromised but not completely deficient in interaction with Miz1. Very similar results were obtained for expression of $c d k n 1 c$ and also $c d k n 1 a$ mRNAs (Fig. 4C).

To confirm that the difference in expression in lymphomas is not due to clonal variation but reflects an inherent difference in the ability of Myc and MycV394D to
A

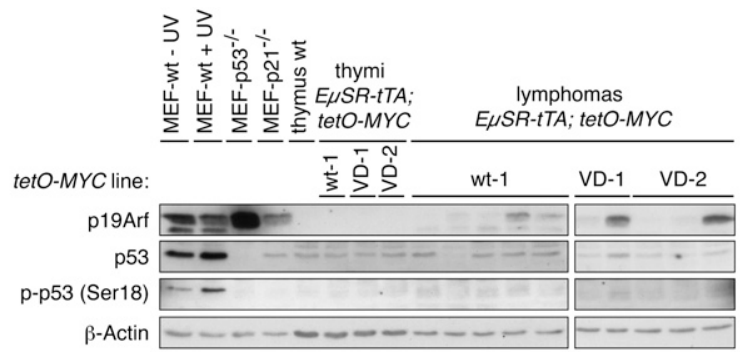

$\mathrm{B}$

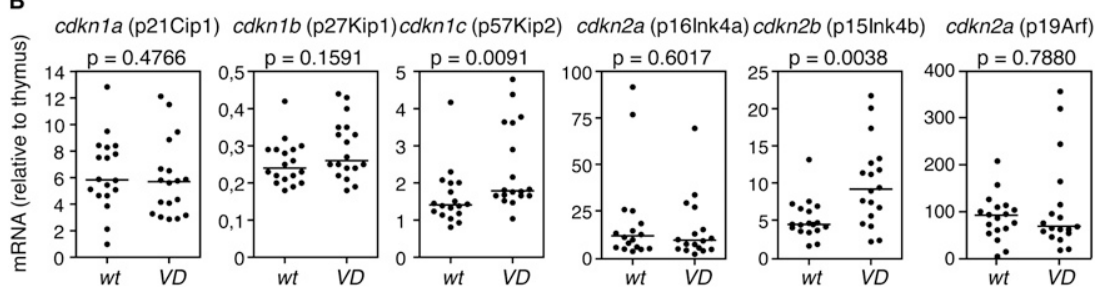

Figure 3. Elevated expression of $c d k 2 n b$ and $c d k n 1 c$ expression in lymphomas expressing MycV394D. (A) Immunoblots documenting the expression of the indicated proteins in lymphomas of mice of the indicated genotypes. For comparison, prelymphomagenic and control thymi are included as indicated. Furthermore, lysates of mouse embryo fibroblasts are shown; where indicated, these cells were exposed to UVB irradiation prior to harvesting to induce Atr-dependent phosphorylation of p53 at Ser18. (B) RQ-PCR analysis documenting expression of the indicated mRNAs in lymphomas expressing either wild-type Myc or MycV394D. Each dot indicates expression in one individual lymphoma. The $Y$-axis shows expression levels relative to the thymus of a nontransgenic mouse. $P$-values refer to the difference between the two different genotypes, and were calculated using a two-tailed MannWhitney test. 
A

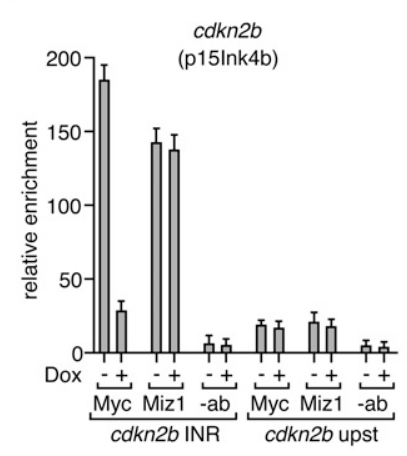

B

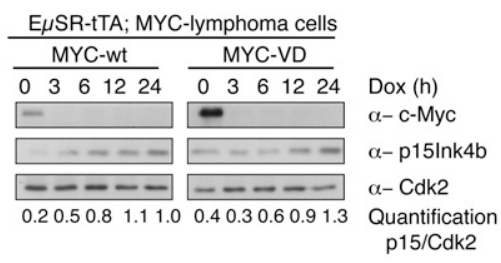

C

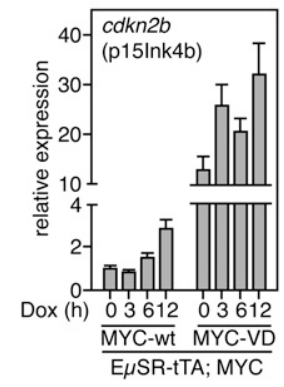

D

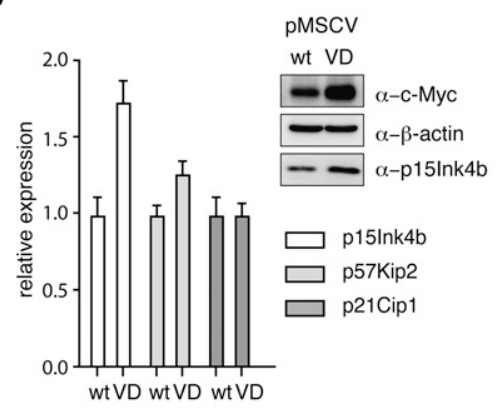

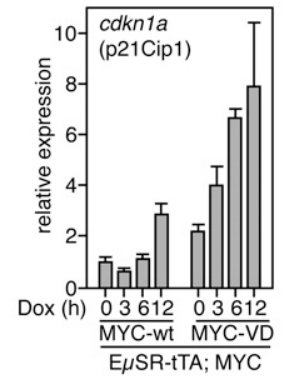

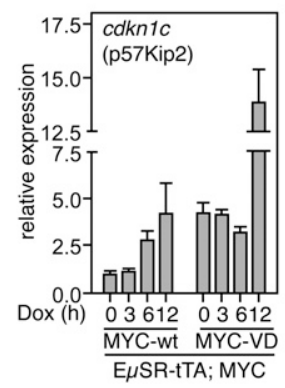

E

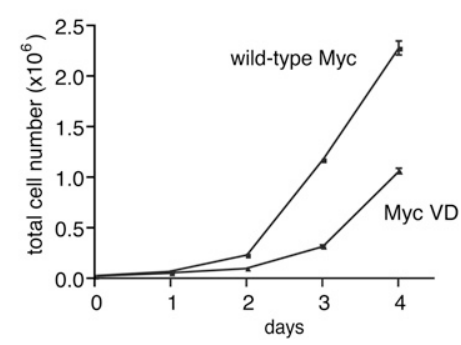

Figure 4. The Myc/Mizl complex is continuously required to suppress expression of $c d k 2 n b$ and $c d k n 1 c$ in T-cell lymphomas. $(A)$ ChIP assays demonstrating the doxycyclineregulated presence of Myc and the constitutive presence of Mizl at the start sites of the $c d k n 2 b$ gene in T-cell lymphomas. Lymphoma cells either were harvested untreated or, where indicated, doxycycline was added to the medium and cells were harvested $24 \mathrm{~h}$ later. Relative enrichment of Myc and Mizl at the $c d k n 2 b$ transcription start site is shown compared with a -1 -kb upstream control region. (B) Summary of the time course experiments of cultured lymphoma cells expressing either Myc or MycV394D in response to addition of doxycycline. Immunoblots were probed with antibodies directed against Myc(9E10), p15Ink4b, and Cdk2. Cells were grown in culture in the absence of doxycycline, or were harvested at the indicated times after addition of doxycycline. $(C)$ Lymphoma cells shown in $B$ were analyzed by RQ-PCR assays documenting the expression of $c d k n 2 b$, $c d k n 1 a$, and $c d k n 1 c$ mRNAs under these experimental conditions. (D) Lymphoma cells expressing doxycycline-regulated wild-type Myc were infected with retroviruses that constitutively express either wild-type Myc or MycV394D. After selection, doxycycline was added to switch off expression of the doxycycline-regulated Myc allele, and cells were harvested $48 \mathrm{~h}$ later. Control experiments established that the doxycycline-regulated Myc is undetectable after $6 \mathrm{~h}$. The panels show RQPCR and immunoblot analysis documenting expression of the indicated mRNAs and proteins. (E) Growth curve documenting the growth of cells described in $C$ in the presence of doxycycline. repress expression of both genes in lymphoma cells, we infected lymphoma cells that expresses a tetracyclineregulated allele of wild-type Myc with retroviruses that constitutively express wild-type Myc or MycV394D and switched off the expression of the tetracycline-regulated allele by addition of doxycycline. Under these conditions, only the retroviral Myc allele is expressed. The subsequent analysis showed that lymphoma cells expressing MycV394D displayed elevated levels of $c d k n 2 b$ mRNA and $\mathrm{p} 15 \mathrm{Ink} \mathrm{kb}$ protein relative to cells expressing wild-type Myc, although they robustly expressed the MycV394D protein (Fig. 4D). Indeed, we consistently observed that MycV394D was expressed at slightly elevated levels in these assays, most likely since it is compromised in its ability to induce apoptosis (Patel and McMahon 2006). MycV394D cells also displayed moderately elevated levels of $c d k n 1 c$ mRNA, whereas expression of $c d k n 1 a$ mRNA was unaltered, closely mimicking the phenotype observed in lymphomas. Furthermore, vector-infected lymphoma cells completely ceased proliferation in the presence of doxycycline (data not shown). Cells infected with viruses expressing wild-type Myc grew robustly in the presence of doxycycline, whereas MycV394D was compromised in rescuing growth in the presence of doxycycline (Fig. 4E). Collectively, these data demonstrate that Myc continuously represses expression of $c d k n 2 b$ and $c d k n 1 c$ via interaction with Mizl in lymphoma cells. While lymphomas driven by MycV394D expressed elevated levels of $c d k n 1 a$ in vitro, this was not observed in vivo, suggesting that additional protein interactions of Myc contribute to repression of $c d k n 1 a$ by Myc in vivo (Gartel et al. 2001).

In human fibroblasts, expression of $c d k n 2 b$ is up-regulated by an interleukin-6 (IL6)-dependent autocrine mechanism during oncogene-induced senescence (Kuilman et al. 2008). However, expression of IL6 mRNA did not differ between $\mathrm{T}$ lymphocytes, which do not show any signs of senescence (data not shown), and lymphoma cells, suggesting that IL6 may not play a critical role under these experimental conditions (Supplemental Fig. 4A). In hematopoietic cells, expression of $\mathrm{p} 15 \mathrm{Ink} 4 \mathrm{~b}$ and $\mathrm{p} 57 \mathrm{Kip} 2$ is stimulated by TGF $\beta$, suggesting that TGF $\beta$ might be a physiological inducer of their expression in T-cell lymphomas (Massague 2008). As 
a first test of this hypothesis, we measured the expression of TGF $\beta-1$, TGF $\beta-2$, and TGF $\beta-3$ mRNAs in naïve and in prelymphomagenic T cells expressing either wild-type Myc or MycV394D and in T-cell lymphomas of either genotype (Fig. 5A). Very little expression of any TGF $\beta$ isoform was detected in naïve and prelymphomagenic $\mathrm{T}$ cells. While there was no increase in TGF $\beta-1$ expression, we observed a strong increase in expression of TGF $\beta-2$ and TGF $\beta-3$ in lymphoma cells. There was a trend for MycV394D lym- phomas to express enhanced levels of both TGF $\beta$ isoforms; whether this reflects a direct effect of Myc/Miz1 complexes on the promoter of either gene is currently unknown. Immunohistochemistry using an antibody that recognizes TGF $\beta-2$ confirmed that lymphomas expressed strongly enhanced levels of this protein relative to normal T cells (Fig. 5B).

Engagement of the TGF $\beta$ receptor leads to phosphorylation of the Smad2 and Smad3 transcription factors
A
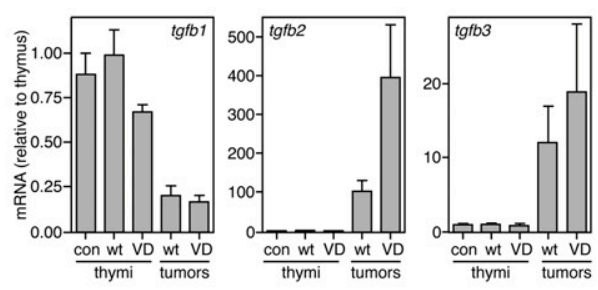

B
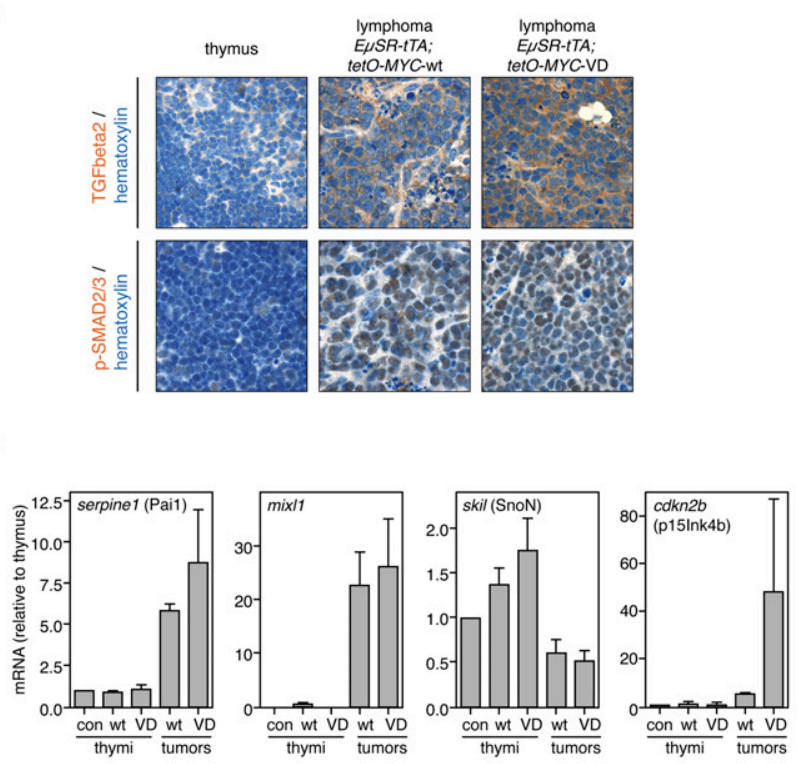
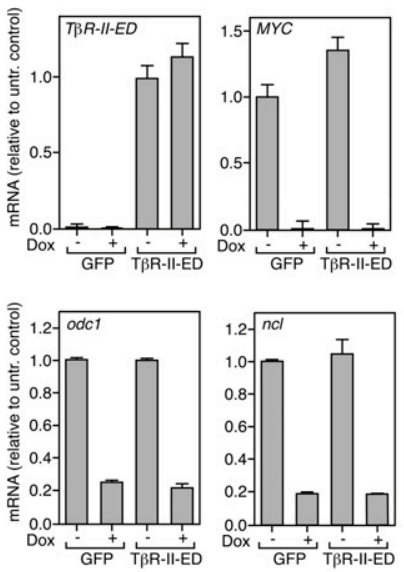

$\mathbf{F}$

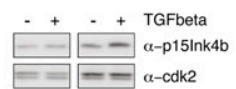

MYC-wt MYC-VD $\overline{\text { E } \mu \mathrm{SR}-\mathrm{TTA} ; \mathrm{MYC}}$

H
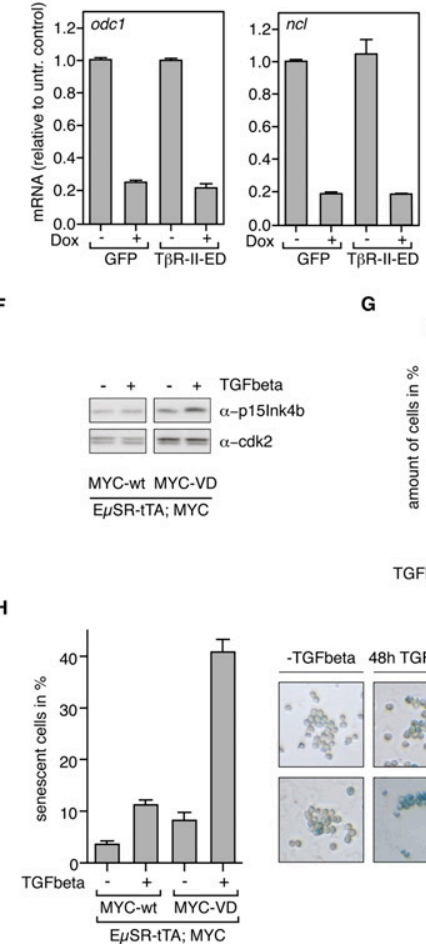

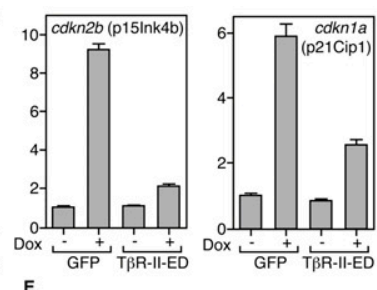

E
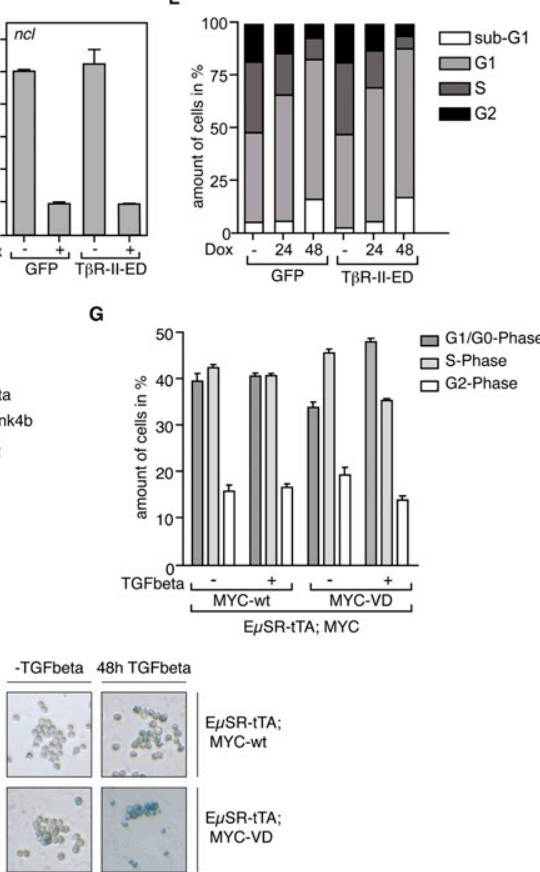

Figure 5. TGF $\beta$-dependent signal transduction is required for expression of cell cycle inhibitors and senescence in cultured lymphoma cells. (A) Activation of the TGF $\beta$ pathway during lymphomagenesis. The panel documents RQ-PCR assays of mRNAs encoding the indicated TGF $\beta$ isoforms in nontransgenic thymus $(n=2)$, in transgenic thymi (wild-type Myc: $n=2 ;$ MycV394D: $n=2$ ), and in lymphoma cells expressing either wild-type Myc $(n=8)$ or MycV394D $(n=11)$. This and the subsequent panels show average expression value of the indicated numbers of samples. Expression in nontransgenic thymus was arbitrarily set to 1 . $(B)$ Immunohistochemistry using antibodies recognizing TGF $\beta-2$ (top row) and phosphorylated Smad 2 and Smad3 (bottom row). The stainings show representative examples of three tumors analyzed for each genotype. $(C)$ RQ-PCR assays documenting the expression of selected downstream target genes of the TGF $\beta$ pathway in the same samples shown in $A$. The panels show expression levels relative to nontransgenic thymus. (D) TGF $\beta$-dependent signaling is required to induce expression of $c d k n 2 b$ and $c d k n 1 a$ when expression of Myc is inhibited. T-cell lymphoma cells were transduced with either control viruses or retroviruses expressing the soluble T $\beta R$-II-ED. Where indicated, doxycycline was added to the medium, and cells were harvested $48 \mathrm{~h}$ later. The panels document RQ-PCR assays measuring the expression of the indicated mRNAs. $(E)$ FACS analysis documenting the accumulation of both control lymphoma cells and of lymphoma cells expressing T $\beta$ R-II-ED in the G1 phase of the cell cycle upon inhibition of Myc expression. $(F)$ Addition of recombinant TGF $\beta 1$ induces p15Ink4b protein expression only in MycV394D-expressing lymphoma cells as shown by immunoblot analysis. (G) Addition of recombinant TGF $\beta 1$ induces cell cycle arrest in lymphoma cells expressing MycV394D, but not in cells expressing wild-type Myc. $(H)$ Addition of recombinant TGF 31 induces senescence in lymphoma cells expressing MycV394D, but not in cells expressing wild-type Myc. Senescence was analyzed using SA- $\beta$-Gal staining. 
(Massague 2008). To test whether the TGF $\beta$ pathway was active in lymphomas, we performed immunohistochemistry using an antibody directed against phosphorylated Smad2 and Smad3 and found that high levels of phosphorylated Smad2/3 proteins were present in the nucleus of T-lymphoma cells expressing either wild-type Myc or MycV394D; in contrast, only weak staining was found in normal T lymphocytes (Fig. 5B). Furthermore, we measured the expression of four target genes of the pathway: pail and mixl1, target genes that are induced by TGF $\beta$ signaling, were expressed at elevated levels in T-cell lymphomas relative to naive and prelymphomagenic T cells (Fig. 5C). In contrast, snon, which is repressed by TGF $\beta$ dependent signals, was expressed at lower levels in T-cell lymphomas. Consistent with these observations, $c d k n 2 b$ was expressed at very low levels in naïve and prelymphomagenic T cells. Its expression was moderately elevated in lymphomas expressing wild-type Myc and strongly elevated in MycV394D lymphomas (Fig. 5C). Taken together, the data show that the TGF $\beta$ pathway is active in T-cell lymphomas, but not in normal and prelymphomagenic T cells, and that Myc suppresses $c d k n 2 b$, but not other target genes of the TGF $\beta$ pathway, via interaction with Mizl. Consistent with the notion that TGF $\beta$ is selectively active in lymphomas, there was no detectable difference in expression of any CKI, including $c d k n 2 b$, between control thymus and prelymphomagenic $\mathrm{T}$ cells expressing either wild-type Myc or MycV394D (Supplemental Fig. 4B).

To define if TGF $\beta$ is indeed the driving force that enhances p15Ink4b expression in lymphoma cells, we expressed the soluble TGF $\beta$ type II receptor extracellular domain (T $\beta$ R-II-ED), which sequesters TGF $\beta$ and thereby blocks TGF $\beta$ signaling, in lymphoma cells expressing wild-type Myc (Fig. 5D; Thomas and Massague 2005). Addition of doxycycline led to a rapid loss of expression of the Myc transgene in both control cells and in cells expressing T $\beta$ R-II-ED (Fig. 5D). Furthermore, this led to a TGF $\beta$-independent down-regulation of two genes that are directly induced by Myc: nucleolin (ncl) and odc1 (Fig. 5D). Consistent with our previous observations, addition of doxycycline led to a strong up-regulation of $c d k n 2 b$ and $c d k n 1 a$ expression. This was abrogated by expression of T $\beta$ R-II-ED, demonstrating that induction of both CKIs requires TGF $\beta$ signaling.

FACS analyses showed that lymphoma cells undergo cell cycle arrest in a TGF $\beta$-independent manner when Myc is switched off, demonstrating that antagonizing TGF $\beta$ signaling is not the only function via which Myc maintains proliferation of lymphoma cells (Fig. 5E). Consistent with this notion, lymphoma cells expressing either Myc or MycV394D undergo cell cycle arrest and apoptosis when Myc is switched off (Supplemental Fig. 5A).

To test whether the response to TGF $\beta$ is the critical determinant of the different growth behavior of lymphoma cells expressing wild-type Myc or MycV394D, we added TGF $\beta$ to lymphoma cells expressing either wild-type Myc or MycV394D. Addition of TGF $\beta$ led to an increase in p15Ink4b expression specifically in lymphoma cells expressing MycV394D, but not in lymphoma cells expressing wild-type Myc (Fig. 5F). Consistent with these findings,
TGF $\beta$ induced accumulation of lymphoma cells expressing MycV394D in the G1 phase of the cell cycle, whereas it had no effect on the cell cycle distribution of lymphoma cells expressing wild-type Myc (Fig. 5G). Similarly, addition of TGF $\beta$ induced an accumulation of senescent cells in cultured lymphomas expressing MycV394D, but not in cells expressing wild-type Myc (Fig. 5H). We also observed that expression of T $\beta$ R-II-ED preferentially accelerated the growth of cells expressing MycV394D, whereas it had little effect on the growth on lymphoma cells expressing wildtype Myc (data not shown). We concluded that the interaction of Myc with Mizl is specifically required to antagonize TGF $\beta$ signaling in the growth of lymphoma cells.

Expression of T $\beta R-I I-E D$ also compromised induction of senescence in lymphoma cells upon addition of doxycycline (Fig. 6A). To extend these findings to an in vivo situation, we injected both control cells and cells expressing T $\beta R-I I-E D$ into syngeneic, immunocompetent mice (FVB/N) (Fig. 6B). After tumor formation, doxycycline was added to the drinking water, and tumors were harvested at different time points thereafter. RQ-PCR analysis showed that expression of $c d k n 2 b$ and $c d k n 1 a$ was induced in a TGF $\beta$-dependent manner in vivo when Myc was switched off. Expression of $c d k n 1 c$ also strongly increased after addition of doxycyline, but was partially independent of TGF $\beta$, arguing that additional signals may contribute to induction of CKI expression in vivo (Fig. 6B). As expected, mRNA levels of odc1 and $n c l$ decreased in a TGF $\beta$-independent manner after addition of doxycycline (Supplemental Fig. 5B). Our previous work has shown that both induction of apoptosis and induction of senescence contribute to tumor regression under these circumstances (Wu et al. 2007). TUNEL staining confirmed the rapid induction of apoptosis when expression of Myc was switched off. Importantly, induction of apoptosis occurred to a similar extent in control cells and in cells expressing T $\beta R-I I-E D$, demonstrating that it occurs independently of TGF $\beta$ (Fig. 6C). In contrast, staining for either SA- $\beta$-Gal (Fig. 6D) or H3K9triMe (Fig. 6E) revealed that lymphomas undergo TGF $\beta$-dependent senescence when Myc is turned off in vivo. Under these conditions, the increase in the percentage of SA- $\beta$-Gal-positive cells closely paralleled the increase in H3K9triMe-positive cells, demonstrating that lymphoma cells undergo "complete" TGF $\beta$-dependent senescence when expression of Myc is switched off in vivo.

Senescence is an irreversible form of growth arrest; furthermore, senescent cells can be eliminated by cells of the innate immune system (Xue et al. 2007). Hence, the induction of senescence might contribute to stable tumor regression when Myc is switched off. Indeed, depletion of either p16Ink4a or its downstream mediator, the retinoblastoma protein, facilitates relapse when Myc is switched off (Wu et al. 2007). Upon addition of doxycycline, lymphomas regressed rapidly, independently of whether they express T $\beta R$-II-ED. However, lymphomas expressing T $\beta$ RII-ED relapsed significantly more rapidly compared with controls when doxycycline was added continuously to the drinking water of mice, consistent with the notion of TGF $\beta$ being critical for enforcing senescence (Fig. 7). 
A

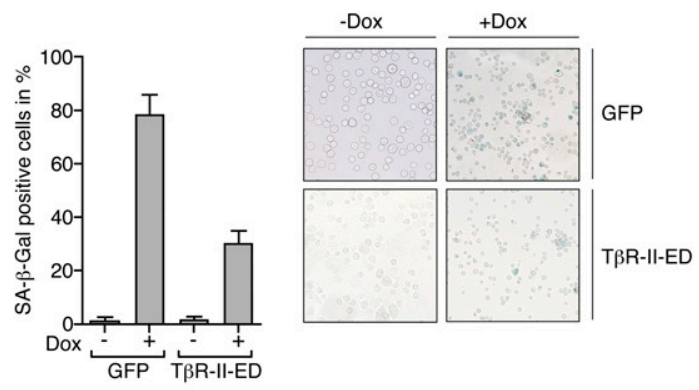

B

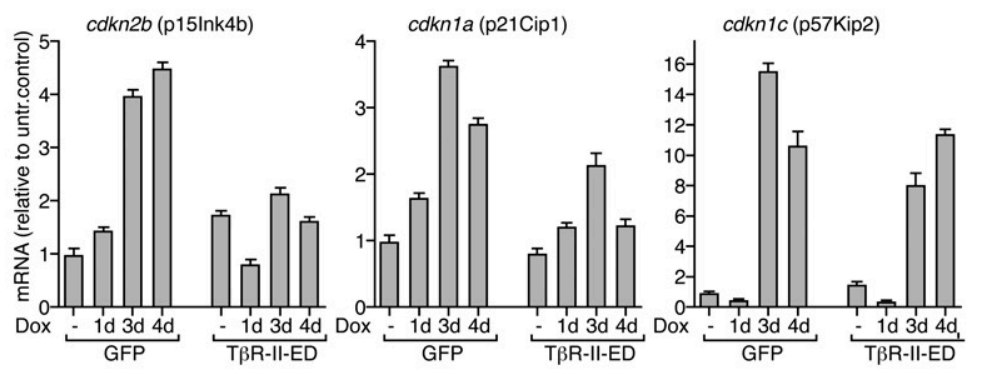

C
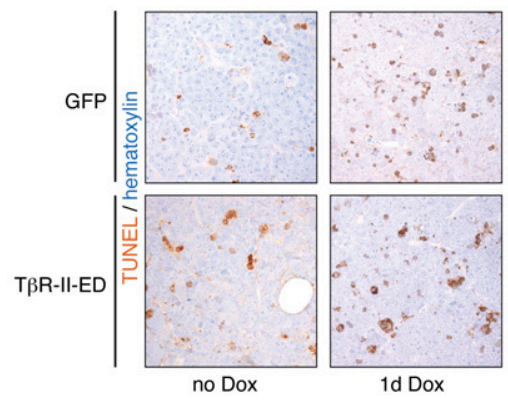

1d Dox

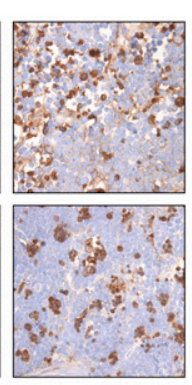

3d Dox

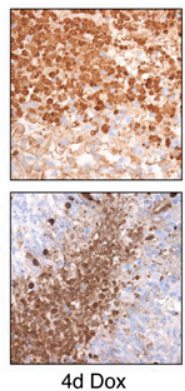

D
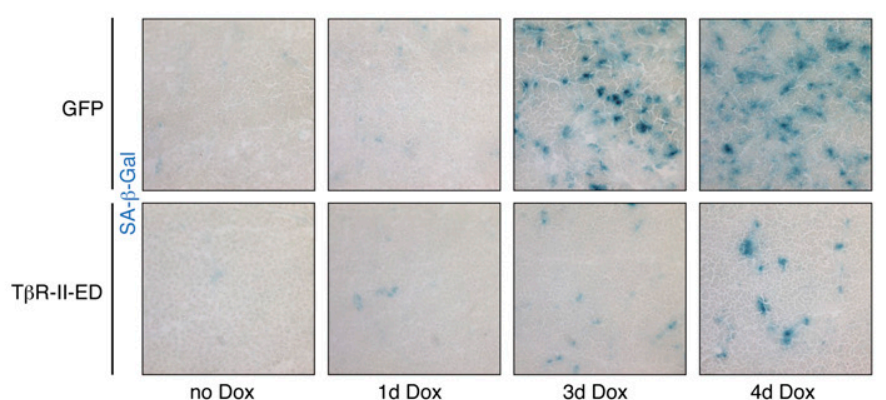

3d Dox

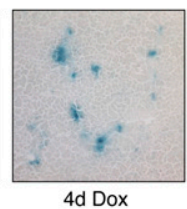

E
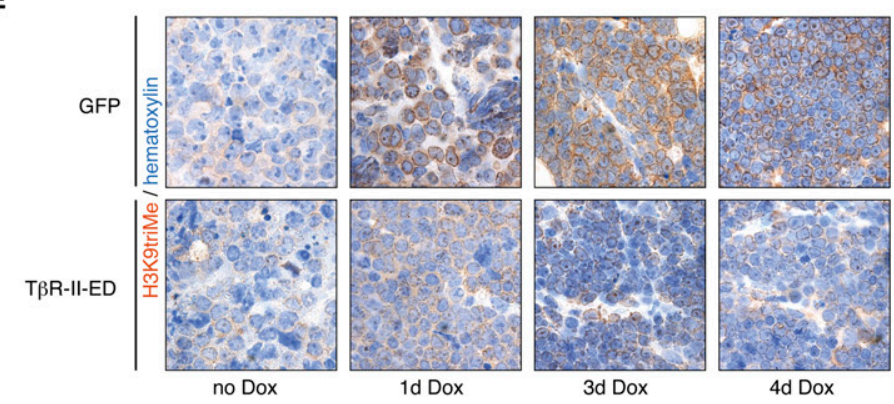

Figure 6. TGF $\beta$-dependent senescence occurs in vivo. (A) TGF $\beta$-dependent signal transduction is required for induction of senescence when Myc is turned off. The panel shows the percentage of either control lymphoma cells ("GFP") or cells expressing T $\beta R$-II-ED that stain positive for SA- $\beta$-Gal in response to addition of doxycycline. (B) TGF $\beta$-dependent signal transduction regulates expression of CKIs in vivo. Control lymphoma cells and cells expressing T $\beta$ R-II-ED were injected subcutaneously into syngeneic, immunocompetent mice (FVB/N). After palpable tumors had developed, doxycycline was added to the drinking water where indicated, and tumors were recovered at the indicated times thereafter. The panels document RQ-PCR assays analyzing expression of the indicated genes. $(C)$ Induction of apoptosis occurs independently of TGF $\beta$ in T-cell lymphomas when expression of Myc is switched off. Mice were injected and tumors harvested as described above. The panels show representative sections of lymphoma tissues stained by TUNEL to visualize apoptotic cells. (D) TGF $\beta$-dependent induction of senescence in T-cell lymphomas. The experiment was performed as before, and sections were frozen and stained for SA- $\beta$-Gal. (E) Parallel sections to those shown in $B$ were stained for H3K9triMe. 


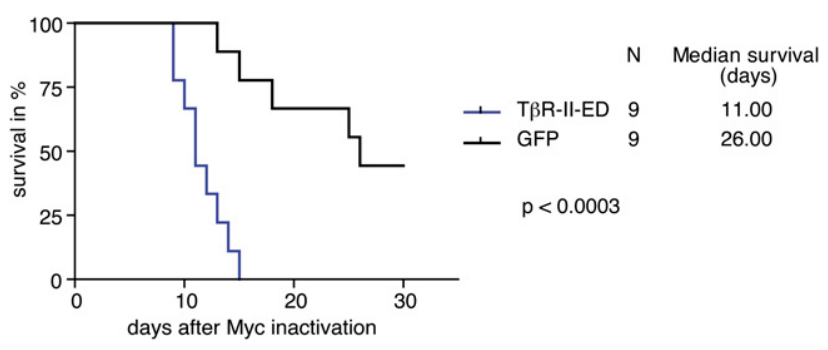

Figure 7. TGF $\beta$-dependent senescence is required for sustained regression when expression of Myc is reversed. Mice were injected as described above, and doxycycline was added to the drinking water when palpable tumors had developed. Subsequently, mice were monitored for relapse.

The data strongly support the view that TGF $\beta$-dependent senescence contributes to stable remission under these circumstances.

\section{Discussion}

We demonstrate that the ability of Myc to form a repressive complex with the Mizl transcription factor is important for Myc to induce and maintain lymphomagenesis. We suggest a model (Fig. 8) in which the interaction of Myc with Mizl antagonizes the ability of the TGF $\beta$ pathway to suppress proliferation and induce characteristic features of senescence. We show that, by suppressing Myc to physiologic levels, we restore growth inhibition and induction of senescence by the TGF $\beta$ pathway, which is critical to elicit sustained tumor regression and oncogene addiction. This autocrine regulatory circuit is important for the ability of Myc to induce tumorigenesis, and the mechanism by which Myc inactivation induces tumor regression.

Four key observations demonstrate that the interaction of Myc with Mizl is critical for lymphomagenesis: First, lymphomagenesis induced by a point mutant of Myc (MycV394D) that is unable to bind to Mizl but retains the ability to bind to Max and activate transcription is significantly delayed relative to lymphomagenesis induced by wild-type Myc. The delay is observed in three inde- pendent founder mice and under conditions where both the level of transgene expression and its temporal order are strictly controlled, strongly arguing that it is due to an intrinsic defect of the MycV394D allele in tumor induction. Second, expression levels of $c d k n 2 b$ and $c d k n 1 c$, two genes that are repressed by Myc and Mizl in tissue culture, are elevated in lymphomas generated by MycV394D relative to those expressing wild-type Myc. Third, ChIP experiments demonstrate that both Myc and Mizl are present at the $c d k n 2 b$ promoter in lymphoma cells. Fourth, reversing oncogene expression either in vitro or in vivo shows that the Myc/Mizl complex is continuously required to repress $c d k n 2 b$ and $c d k n 1 c$ expression in T-cell lymphomas.

Our results can be interpreted in light of several previous studies that have used Myc-dependent lymphoma models to decipher the role of downstream target genes of Myc. Notably, both odc1 and rpl24 are haploinsufficient for Myc-dependent lymphomagenesis, but not for normal development, strongly arguing that their enhanced expression in Myc-induced tumors is critical for tumor development (Nilsson et al. 2005; Barna et al. 2008). Importantly, Myc-induced increases in protein synthesis and odc1 expression are apparent in the prelymphomagenic state. In contrast, we did not observe any difference in expression of any CKI in prelymphomagenic $\mathrm{T}$ cells. The difference between wild-type Myc and MycV394D becomes manifest only in lymphomas, and is due to a strong increase in TGFß synthesis upon lymphoma formation. The mechanism that causes this increase remains to be resolved. Notably, expression of both TGF $\beta-2$ and TGF $\beta-3$ closely parallels that of p19Arf in this tumor model, and all three genes may therefore respond to oncogenic stress signals that are specifically present in tumor cells (see Fig. 4A; Supplemental Fig. 3A,B). Furthermore, other cells that are present in a tumor can act as sources of TGF $\beta$ in vivo: For example, apoptosis of lymphoma cells attracts macrophages that secrete TGF $\beta 1$ in a Myc-driven model of B-cell lymphomagenesis (Reimann et al. 2010).

Relative to lymphomas expressing wild-type Myc, lymphomas induced by MycV394D expressed elevated

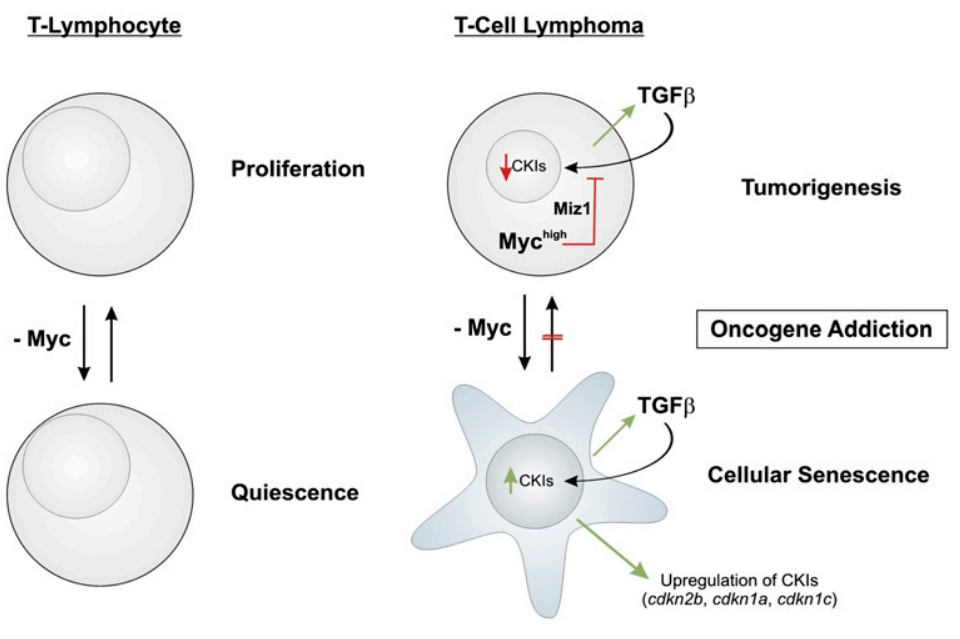

Figure 8. A model for oncogene addiction of Myc-induced T-cell lymphomas. We suggest that, since lymphoma cells express high levels of TGF $\beta$, there is a constant pressure to elicit an autocrine program of differentiation and senescence, which is absent in normal lymphocytes. 
levels of $\mathrm{p} 27$ and decreased levels of Cdk1 and incorporated less BrdU, clearly indicating a defect in cell proliferation. At the same time, the vast majority of lymphoma cells of either genotype express Ki67. Ki67 is expressed in the mid-G1 phase of proliferating cells, but not in resting cells; therefore, the presence of Ki67 indicates that these cells have not exited from the cell cycle (Gerdes et al. 1984). These findings strongly suggest a model in which E-box-dependent activation by Myc is sufficient to prevent exit from the cell cycle, but that binding of Myc to Miz1 is required to enforce rapid proliferation and lymphoma development.

Consistent with the delay in proliferation, a large fraction of cells in lymphomas expressing MycV394D stain positive for H3K9triMe. The accumulation of H3K9triMe is an indicator of senescence, and the enzyme that catalyzes this modification (Suv39h1) is causally required for senescence in models of B-cell lymphomagenesis (Braig et al. 2005; Reimann et al. 2010). Indeed, MycV394Ddriven lymphomas contain a significant population of cells that stain positive for both histone H3K9triMe and Ki67, suggesting that the accumulation of $\mathrm{H} 3 \mathrm{~K} 9$ triMe may prevent cell cycle progression of these cells. One possible explanation is provided by the observation that $\mathrm{H} 3 \mathrm{~K} 9$ triMe accumulates on target genes of the E2F transcription factor in senescent cells, correlating with stable repression of these genes and cell cycle arrest (Narita et al. 2003).

Lymphoma cells accumulated both H3K9triMe and a second marker of senescence, SA- $\beta$-Gal, in a TGF $\beta$-dependent manner when the Myc transgene was turned off either in vitro or in vivo. SA- $\beta$-Gal also accumulated when lymphoma cells driven by Myc394D, but not by wild-type Myc, were treated with TGF $\beta$ in vitro. In contrast, SA$\beta$-Gal did not accumulate to the same extent as H3K9triMe in lymphomas expressing MycV394D in vivo. The molecular processes that cause accumulation of SA- $\beta$-Gal in senescent cells are poorly understood; therefore, the precise reason for the varying degree to which accumulation of SA$\beta$-Gal reflects the biological differences of lymphoma cells expressing wild-type Myc or MycV394D in both assays remains to be determined.

To determine the basis of the delayed proliferation of MycV394D lymphomas, we considered that there are at least two mechanistically distinct processes that are known to contribute to oncogene-induced senescence: First, senescence occurs in a p53-dependent manner in response to either DNA damage or expression of the Arf tumor suppressor protein (Kamijo et al. 1997; Di Micco et al. 2006). Several arguments suggest that this process is not causally involved in the senescence observed here: Specifically, analysis of expression levels of p53 or Arf, monitoring the phosphorylation status of p53 and one of its upstream regulators, Chk1, and sequencing of the DNA encoding the DNA-binding domain of p53 in lymphomas expressing either wild-type Myc or MycV394D revealed no evidence for activation of the p53 pathway during lymphoma development in this tumor model.

Senescence can also occur in response to secretion of multiple cytokines, and the enhanced synthesis of IL6 accounts for the oncogene-induced senescence of human primary fibroblasts (Coppe et al. 2008; Kuilman et al. 2008). IL6 induces senescence via up-regulation of $c d k n 2 b$ and $c d k n 2 a$, but is not regulated in the cells studied here (Kuilman et al. 2008). Instead, TGF $\beta$ - 2 and TGF $\beta-3$ are key inducers of cell cycle arrest and senescence in these lymphomas; conceptually, secretion of TGF $\beta-2$ and TGF $\beta-3$ by lymphoma cells is similar to the secretory senescence described in these studies.

How does TGF $\beta$ suppress proliferation and enforce a senescence-like state specifically in lymphoma cells expressing MycV394D? TGF $\beta$ antagonizes transactivation by Myc via up-regulation of MXD1 (Mad1), thereby enforcing senescence in human myeloid cells (Wu et al. 2009). Similar mechanisms may explain the ability of TGF 1 to maintain some degree of senescence in B-cell lymphomas that express Myc constitutively (Reimann et al. 2010). However, microarray analysis did not reveal an effect of TGF $\beta$ on expression of any $m x d$ mRNA in the cells studied here (data not shown). Furthermore, the observation that virtually all MycV394D lymphoma cells stain positive for Ki67, whereas cells become Ki67negative when Myc is switched off, argues that Myc function is not generally compromised in MycV394D lymphoma cells. Relative to lymphomas driven by wildtype Myc, lymphomas driven by MycV394D express elevated levels of $c d k n 2 b$ and $c d k n 1 c$ mRNAs and elevated levels of the Cdk2 inhibitor p27Kip1, arguing that Cdk2 activity is compromised in these lymphomas. Notably, Cdk2 has been shown recently to have a specific role in suppressing senescence of Myc-transformed cells (Campaner et al. 2010). This is at least in part due to the fact that Cdk2 phosphorylates Ser 62; since phosphorylation of Ser 62 is required for activation of a subset of Myc target genes, cyclin $\mathrm{E} / \mathrm{Cdk} 2$ is a coactivator for a subset of Myc target genes (Benassi et al. 2006; Hydbring et al. 2010). Taken together, the data suggest a model in which the failure of MycV394D to repress $c d k n 2 b$ and $c d k n 1 c$ expression slows cell cycle progression beyond the G1 phase of the cell cycle, and that the low levels of Cdk2 activity enforce a senescence-like state in these cells.

TGF $\beta$ may contribute to tumor regression through several mechanisms. For example, senescent cells are targeted by the innate immune system (Xue et al. 2007). Also, crossing mice expressing MycV394D onto a $c d k n 2 b^{-/-}$background did not significantly accelerate lymphomagenesis; therefore, CKIs are unlikely to be the only TGF $\beta$-dependent genes that are regulated by Myc via Mizl (data not shown). Consistent with this notion, extensive microarray experiments revealed that TGF $\beta$-induced senescence is not restricted to enhanced CKI expression, but also involves the enhanced expression of genes that are characteristic for several developmental lineages, and that sustained expression of high levels of Myc is required to block this expression of lineage-specific genes during lymphomagenesis (JM and ME, unpubl.). Since the oncogenic properties of Myc strongly depend on the developmental state of its target tissue, it is possible that the-so far unidentifiedmolecular changes that underlie the enhanced expression of lineage-specific genes in response to TGF $\beta$ prevent tumor 
recurrence once the Myc transgene has been turned off (Beer et al. 2004).

Our results may also have potentially important mechanistic implications not only for how Myc initiates tumorigenesis, but also for how Myc inactivation induces oncogene addiction and tumor regression (Weinstein 2002; Felsher 2008). They suggest that autocrine regulatory pathways may play an essential role in oncogene addiction. We show that lymphoma cells express high levels of TGF $\beta$, and thereby are poised to elicit an autocrine program of senescence once this pathway is restored upon Myc inactivation, and that this contributes to sustained tumor regression. Hence, when physiologic levels of Myc are restored in a tumor, senescence programs become manifest as long as the TGF $\beta$ pathway is still functional. Notably, the blockade of TGF $\beta$ signaling did not affect initial tumor regression. Consistent with our earlier reports, inactivation of Myc induced proliferative arrest, apoptosis, and senescence (Wu et al. 2007). The abrogation of TGF $\beta$ signaling greatly inhibited induction of cellular senescence and resulted in a markedly increased frequency of tumor reoccurrence, demonstrating that a functional TGF $\beta$ pathway is essential for the permanent elimination of tumor cells.

\section{Materials and methods}

\section{Animal experiments}

The generation and characterization of transgenic mouse lines for conditional expression of MYC (TetO-MYC) have been described (Felsher and Bishop 1999). All animal experiments were performed in accordance with the guidelines from the Administrative Panel on Laboratory Animal Care at Stanford University (protocol 14045). To turn off MYC transgene expression in mice, drinking water was supplemented with $200 \mu \mathrm{g} / \mathrm{mL}$ doxycycline.

\section{Tumor surveillance assay}

To monitor tumor growth, regression, and relapse, the percent tumor-free survival was measured as the time between doxycycline treatment (if tumor regression occurred within $1 \mathrm{wk}$ ) and relapse, which is defined as recurrence of signs of morbidity. Statistical comparison of Kaplan-Meier curves is based on the logrank test. For transplantation experiments, $10 \times 10^{6}$ cells were washed once in PBS before subcutaneous injection into FVB/N syngeneic mice. To assess for tumor regression, the dimensions of transplanted subcutaneous tumors were measured by using a caliper over a 30-d period of doxycycline treatment, and tumor volumes were calculated by using the formula length $(\mathrm{mm}) \times$ width $^{2}\left(\mathrm{~mm}^{2}\right) \times 0.52$.

\section{Cell culture}

Cell lines derived from murine T-cell lymphoma were grown in RPMI1640 supplemented with $10 \%$ FBS, $1 \%$ penicillin/streptomycin, 1\% 1-glutamine, and $50 \mu \mathrm{M} 2$-mercaptoethanol. To turn off expression of the MYC transgene, cells were treated with doxycycline at $20 \mathrm{ng} / \mathrm{mL}$ for the indicated times.

\section{Immunohistochemistry}

Transplanted subcutaneous tumors were harvested and fixed in neutral buffered $10 \%$ formalin for paraffin sections. Tissue sections were cut from paraffin-embedded blocks and placed on glass slides. Hematoxylin and eosin (H\&E) staining was performed using standard procedures. The Stanford Histology Core laboratory prepared paraffin sections and performed H\&E staining. Antibodies used are listed in Supplemental Table 3. SA$\beta$-Gal activity in cell lines and tumors was detected as described previously (Serrano et al. 1997).

\section{Analysis of gene expression}

Total RNA was isolated from snap-frozen cell lines or mouse tissue using the RNeasy Kit including DNase-I digest (Qiagen) following the manufacturer's protocol. Two micrograms of RNA was reverse-transcribed into cDNA using Oligo $(\mathrm{dT})_{12-18}$ primers (Invitrogen) and SuperScript II Reverse Transcriptase (Invitrogen). Real-time PCR was performed using SYBR Green (ABI) in an ABI Prizm analyzer. Sequences for quantitative PCR primers are listed in Supplemental Table 1.

\section{ChIP assay}

A ChIP assay was performed using the Upstate Cell Signaling Solutions Kit according to the manufacturer's instructions. Cells were cross-linked with $1 \%$ formaldehyde for $10 \mathrm{~min}$ at $37^{\circ} \mathrm{C}$, and were washed with ice-cold PBS containing proteinase inhibitor cocktail Complete (Roche Diagnostics). After lysis of $2 \times 10^{6}$ cells, the DNA was sheared into 200- to 1000-base-pair fragments by sonification and immunoprecipitated with $2 \mu \mathrm{g}$ of anti-Myc and anti-Miz-1 antibodies. Antibodies and sequences for ChIP-QPCR primers are listed in Supplemental Tables 2 and 3.

\section{FACS analysis}

For cell cycle analysis of lymphoma cell lines, propidium iodide was used. Cells were harvested and fixed in $70 \%$ ethanol and stained with a $0.1 \%$ Triton X-100 solution in PBS containing $0.22 \mathrm{mg} / \mathrm{mL}$ RNase A and $20 \mu \mathrm{g} / \mathrm{mL}$ propidium iodide. The DNA content was measured using a Becton Dickinson flow cytometer.

\section{Acknowledgments}

We thank Anton Berns for the gift of $c d k n 2 b^{-/-}$mice. This study was supported by grants from the Deutsche Forschungsgemeinschaft via Transregio 17 ("Ras-dependent pathways in human cancer") and from the Sander-Stiftung to M.E. J.v.R. was supported by the Lymphoma Research Foundation. D.W.F. is supported by grants from the NIH, the Leukemia and Lymphoma Society, and the Burroughs Wellcome Fund.

\section{References}

Adhikary S, Peukert K, Karsunky H, Lutz W, Elsässer HP, Möröy T, Eilers M. 2003. Mizl is required for early embryonic development during gastrulation. Mol Cell Biol 23: 76487657.

Barna M, Pusic A, Zollo O, Costa M, Kondrashov N, Rego E, Rao PH, Ruggero D. 2008. Suppression of Myc oncogenic activity by ribosomal protein haploinsufficiency. Nature 456: 971975.

Beer S, Zetterberg A, Ihrie RA, McTaggart RA, Yang Q, Bradon N, Arvanitis C, Attardi LD, Feng S, Ruebner B, et al. 2004. Developmental context determines latency of MYC-induced tumorigenesis. PLoS Biol 2: E332. doi: 10.1371/journal. pbio.0020332.

Benassi B, Fanciulli $M$, Fiorentino F, Porrello A, Chiorino G, Loda M, Zupi G, Biroccio A. 2006. c-Myc phosphorylation is 
required for cellular response to oxidative stress. Mol Cell 21: 509-519.

Braig M, Lee S, Loddenkemper C, Rudolph C, Peters AH, Schlegelberger B, Stein H, Dorken B, Jenuwein T, Schmitt CA. 2005. Oncogene-induced senescence as an initial barrier in lymphoma development. Nature 436: 660-665.

Campaner S, Doni M, Hydbring P, Verrecchia A, Bianchi L, Sardella D, Schleker T, Perna D, Tronnersjo S, Murga M, et al. 2010. Cdk2 suppresses cellular senescence induced by the c-myc oncogene. Nat Cell Biol 12: 54-59.

Collado M, Gil J, Efeyan A, Guerra C, Schuhmacher AJ, Barradas M, Benguria A, Zaballos A, Flores JM, Barbacid M, et al. 2005. Tumour biology: Senescence in premalignant tumours. Nature 436: 642.

Coppe JP, Patil CK, Rodier F, Sun Y, Munoz DP, Goldstein J, Nelson PS, Desprez PY, Campisi J. 2008. Senescence-associated secretory phenotypes reveal cell-nonautonomous functions of oncogenic RAS and the p53 tumor suppressor. PLOS Biol 6: 2853-2868.

D'Cruz CM, Gunther EJ, Boxer RB, Hartman JL, Sintasath L, Moody SE, Cox JD, Ha SI, Belka GK, Golant A, et al. 2001. c-MYC induces mammary tumorigenesis by means of a preferred pathway involving spontaneous Kras2 mutations. Nat Med 7: 235-239.

Di Micco R, Fumagalli M, Cicalese A, Piccinin S, Gasparini P, Luise C, Schurra C, Garre M, Nuciforo PG, Bensimon A, et al. 2006. Oncogene-induced senescence is a DNA damage response triggered by DNA hyper-replication. Nature 444: 638-642.

Eilers M, Eisenman RN. 2008. Myc's broad reach. Genes Dev 22: 2755-2766.

Felsher DW. 2008. Oncogene addiction versus oncogene amnesia: Perhaps more than just a bad habit? Cancer Res 68: 3081-3086.

Felsher DW, Bishop JM. 1999. Reversible tumorigenesis by MYC in hematopoietic lineages. Mol Cell 4: 199-207.

Gartel AL, Ye X, Goufman E, Shianov P, Hay N, Najmabadi F, Tyner AL. 2001. Myc represses the p21(WAF1/CIP1) promoter and interacts with Sp1/Sp3. Proc Natl Acad Sci 98: 4510-4515.

Gebhardt A, Frye M, Herold S, Benitah SA, Braun K, Samans B, Watt FM, Elsasser HP, Eilers M. 2006. Myc regulates keratinocyte adhesion and differentiation via complex formation with Miz1. J Cell Biol 172: 139-149.

Gerdes J, Lemke H, Baisch H, Wacker HH, Schwab U, Stein H. 1984. Cell cycle analysis of a cell proliferation-associated human nuclear antigen defined by the monoclonal antibody Ki-67. J Immunol 133: 1710-1715.

Herkert B, Dwertmann A, Herold S, Abed M, Naud J, Finkernagel F, Harms GS, Orian A, Wanzel M, Eilers M. 2010. The Arf tumor suppressor protein inhibits Mizl to suppress cell adhesion and induce apoptosis. J Cell Biol 188: 905-918.

Herold S, Wanzel M, Beuger V, Frohme C, Beul D, Hillukkala T, Syvaoja J, Saluz HP, Hänel F, Eilers M. 2002. Negative regulation of the mammalian UV response by Myc through association with Miz-1. Mol Cell 10: 509-521.

Hydbring P, Bahram F, Su Y, Tronnersjo S, Hogstrand K, von der Lehr N, Sharifi HR, Lilischkis R, Hein N, Wu S, et al. 2010. Phosphorylation by Cdk2 is required for Myc to repress Rasinduced senescence in cotransformation. Proc Natl Acad Sci 107: 58-63.

Kamijo T, Zindy F, Roussel MF, Quelle DE, Downing JR, Ashmun RA, Grosveld G, Sherr CJ. 1997. Tumor suppression at the mouse INK4a locus mediated by the alternative reading frame product p19ARF. Cell 91: 649-659.

Knoepfler PS, Cheng PF, Eisenman RN. 2002. N-myc is essential during neurogenesis for the rapid expansion of progenitor cell populations and the inhibition of neuronal differentiation. Genes Dev 16: 2699-2712.

Kuilman T, Michaloglou C, Vredeveld LC, Douma S, van Doorn R, Desmet CJ, Aarden LA, Mooi WJ, Peeper DS. 2008. Oncogene-induced senescence relayed by an interleukindependent inflammatory network. Cell 133: 1019-1031.

Kumagai A, Dunphy WG. 1991. The cdc25 protein controls tyrosine dephosphorylation of the cdc2 protein in a cell-free system. Cell 64: 903-914.

Malumbres M, Perez De Castro I, Hernandez MI, Jimenez M, Corral T, Pellicer A. 2000. Cellular response to oncogenic ras involves induction of the $\mathrm{Cdk} 4$ and $\mathrm{Cdk} 6$ inhibitor p15(INK4b). Mol Cell Biol 20: 2915-2925.

Massague J. 2008. TGF $\beta$ in cancer. Cell 134: 215-230.

Missero C, Di Cunto F, Kiyokawa H, Koff A, Dotto GP. 1996. The absence of p21Cip1/WAF1 alters keratinocyte growth and differentiation and promotes ras-tumor progression. Genes Dev 10: 3065-3075.

Narita M, Nunez S, Heard E, Lin AW, Hearn SA, Spector DL, Hannon GJ, Lowe SW. 2003. Rb-mediated heterochromatin formation and silencing of E2F target genes during cellular senescence. Cell 113: 703-716.

Nilsson JA, Keller UB, Baudino TA, Yang C, Norton S, Old JA, Nilsson LM, Neale G, Kramer DL, Porter CW, et al. 2005. Targeting ornithine decarboxylase in Myc-induced lymphomagenesis prevents tumor formation. Cancer Cell 7: 433444.

Oskarsson T, Essers MA, Dubois N, Offner S, Dubey C, Roger C, Metzger D, Chambon P, Hummler E, Beard P, et al. 2006. Skin epidermis lacking the c-Myc gene is resistant to Rasdriven tumorigenesis but can reacquire sensitivity upon additional loss of the p21Cip1 gene. Genes Dev 20: 20242029.

Oster SK, Ho CS, Soucie EL, Penn LZ. 2002. The myc oncogene: Marvelously complex. Adv Cancer Res 84: 81-154.

Patel JH, McMahon SB. 2006. Targeting of Miz-1 is essential for Myc-mediated apoptosis. J Biol Chem 281: 3283-3289.

Pelengaris S, Khan M, Evan GI. 2002. Suppression of Mycinduced apoptosis in $\beta$ cells exposes multiple oncogenic properties of Myc and triggers carcinogenic progression. Cell 109: 321-334.

Polyak K, Kato J, Solomon MJ, Sherr CJ, Massague J, Roberts JM, Koff A. 1994. p2 $7^{\mathrm{Kip} 1}$, a cyclin-Cdk inhibitor, links transforming growth factor- $\beta$ contact inhibition to cell cycle arrest. Genes Dev 8: 9-22.

Prieur A, Peeper DS. 2008. Cellular senescence in vivo: A barrier to tumorigenesis. Curr Opin Cell Biol 20: 150-155.

Reimann M, Lee S, Loddenkemper C, Dörr JR, Tabor V, Aichele P, Stein H, Dörken B, Jenuwein T, Schmitt CA. 2010. Tumor stroma-derived TGF- $\beta$ limits myc-driven lymphomagenesis via Suv39h1-dependent senescence. Cancer Cell 17: 262-272.

Seoane J, Pouponnot C, Staller P, Schader M, Eilers M, Massague J. 2001. TGF $\beta$ influences Myc, Miz-1 and Smad to control the CDK inhibitor p15INK4b. Nat Cell Biol 3: 400-408.

Serrano M, Lin AW, McCurrach ME, Beach D, Lowe SW. 1997. Oncogenic ras provokes premature cell senescence associated with accumulation of p53 and p16INK4a. Cell 88: 593602.

Shachaf CM, Kopelman AM, Arvanitis C, Karlsson A, Beer S, Mandl S, Bachmann MH, Borowsky AD, Ruebner B, Cardiff $\mathrm{RD}$, et al. 2004. MYC inactivation uncovers pluripotent differentiation and tumour dormancy in hepatocellular cancer. Nature 431: 1112-1117.

Shieh SY, Ikeda M, Taya Y, Prives C. 1997. DNA damageinduced phosphorylation of p53 alleviates inhibition by MDM2. Cell 91: 325-334. 
van Riggelen et al.

Staller P, Peukert K, Kiermaier A, Seoane J, Lukas J, Karsunky H, Moroy T, Bartek J, Massague J, Hanel F, et al. 2001. Repression of $\mathrm{p} 15 \mathrm{INK} 4 \mathrm{~b}$ expression by Myc through association with Miz-1. Nat Cell Biol 3: 392-399.

Steiger D, Furrer M, Schwinkendorf D, Gallant P. 2008. Maxindependent functions of Myc in Drosophila melanogaster. Nat Genet 40: 1084-1091.

Thomas DA, Massague J. 2005. TGF- $\beta$ directly targets cytotoxic $\mathrm{T}$ cell functions during tumor evasion of immune surveillance. Cancer Cell 8: 369-380.

Weinstein IB. 2002. Cancer. Addiction to oncogenes-The Achilles heal of cancer. Science 297: 63-64.

Wu CH, van Riggelen J, Yetil A, Fan AC, Bachireddy P, Felsher DW. 2007. Cellular senescence is an important mechanism of tumor regression upon c-Myc inactivation. Proc Natl Acad Sci 104: 13028-13033.

Wu S, Hultquist A, Hydbring P, Cetinkaya C, Oberg F, Larsson LG. 2009. TGF- $\beta$ enforces senescence in Myc-transformed hematopoietic tumor cells through induction of Mad1 and repression of Myc activity. Exp Cell Res 315: 3099-3111.

Xue W, Zender L, Miething C, Dickins RA, Hernando E, Krizhanovsky V, Cordon-Cardo C, Lowe SW. 2007. Senescence and tumour clearance is triggered by p53 restoration in murine liver carcinomas. Nature 445: 656-660.

Zindy F, Knoepfler PS, Xie S, Sherr CJ, Eisenman RN, Roussel MF. 2006. N-Myc and the cyclin-dependent kinase inhibitors p18Ink4c and p27Kip1 coordinately regulate cerebellar development. Proc Natl Acad Sci 103: 11579-11583. 


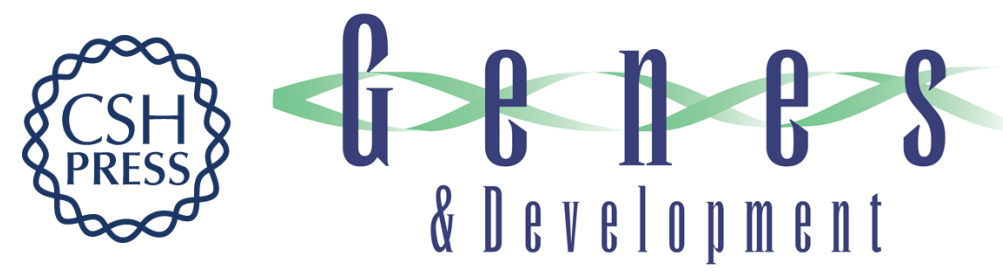

\section{The interaction between Myc and Miz1 is required to antagonize TGF $\beta$ -dependent autocrine signaling during lymphoma formation and maintenance}

Jan van Riggelen, Judith Müller, Tobias Otto, et al.

Genes Dev. 2010, 24:

Access the most recent version at doi:10.1101/gad.585710

Supplemental http://genesdev.cshlp.org/content/suppl/2010/06/09/24.12.1281.DC1

Material

References This article cites 47 articles, 17 of which can be accessed free at:

http://genesdev.cshlp.org/content/24/12/1281.full.html\#ref-list-1

License

Email Alerting Receive free email alerts when new articles cite this article - sign up in the box at the top

Service right corner of the article or click here.

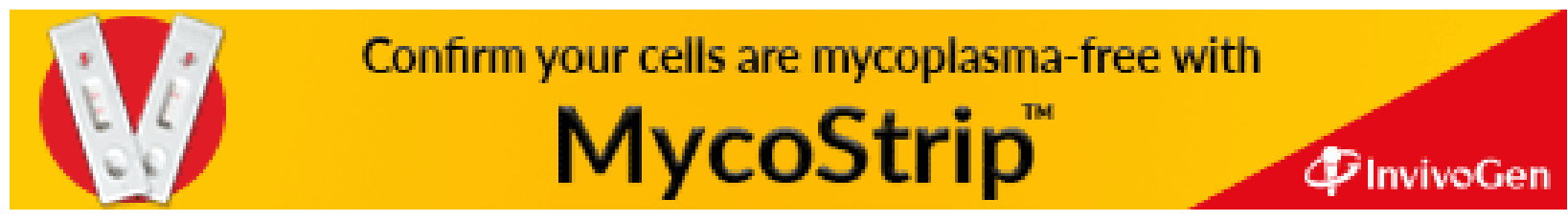

